\title{
SHOWCASING SOCIAL PIETY: BETWEEN CHARITY OF THE HAVES AND RIGHTS OF THE HAVE-NOTS
}

\author{
Miftahur Ridho \\ Institut Agama Islam Negeri Samarinda \\ miftahurridho@gmail.com
}

\begin{abstract}
$R$

eligion based charity organizations, including those inspired by the Islamic teachings regarding caring for others, are prevalent around the world. They play significant role both in supporting the state to deliver social welfare services to the poor and the less fortunate and sidestepping or competing with the state in such provision. This paper, thus, aims at exploring the dynamic interplay between Islamic teachings regarding charitable practices and social welfare services provided by the state. Discussion on this paper suggests that Islamic charitable practices such as Zakat, shadakah, and others, can be observed through different lenses; as a charity of the rich and as rights of the poor. In Indonesia and other Muslim countries, such giving practices are widely accepted as charity of the rich partly because the idea of providing social welfare to the poor is perceived as the duty of the state. Hence, the rights of the poor lies on the obligation of the state, not the rich.
\end{abstract}

Keywods: Islamic charity, zakat, social welfare, Indonesia.

\begin{abstract}
ABSTRAK
I nstitusi kedermawanan berbasis agama, termasuk yang terinspirasi oleh nilai-nilai Islam yang berkaitan dengan kewajiban untuk saling menolong di antara sesama, umum dan marak ditemukan di seluruh dunia. Institusi-institusi tersebut memainkan peran yang sangat penting dalam membantu Negara untuk menghadirkan kesejahteraan social bagi masyarakat miskin dan kurang beruntung. Meski begitu, institusi-institusi tersebut juga di saat yang sama melangkahi peran Negara dalam konteks kesejahteraan sosial masyarakatnya dan memainkan peran sebagai Negara dalam Negara (surrogate state). Artikel ini, oleh sebab itu, berupaya mengeksplorasi hubungan yang dinamis antara praktek-praktek kedermawanan dalam Islam dan peran Negara dalam menyediakan kesejahteraan sosial bagi masyarakat miskin dan kurang mampu di kalangan masyarakat Muslim. Pembahasan dalam artikel ini menunjukkan bahwa praktek kedermawanan dalam Islam seperti Zakat, sedekah, dan yang lainnya dapat dilihat melalui dua sudut pandang, yaitu sebagai kedermawanan dari orang-orang mampu dan sebagai hak dari orang-orang kurang beruntung. Di Indonesia dan NegaraNegara Muslim lainnya, praktek-praktek kedermawanan tersebut secara luas diterima sebagai kedermawanan dari pihak orang-orang mampu. Hal ini sebagianya disebabkan oleh anggapan bahwa menyediakan kesejahteraan sosial bagi orang-orang kurang beruntung merupakan domain dari tugas Negara. Dengan kata lain, hak dari orangorang kurang beruntung berada pada Negara dan bukan berada pada orang-orang kaya.
\end{abstract}

Kata Kunci: kedermawanan, zakat, kesejahteraan sosial, Indonesia. 


\section{INTRODUCTION}

The relation between Islam and charitable activities has been close since the beginning of the religion in the Arabian Peninsula. As a religion, Islam promotes social justice by bringing the idea of equality of all human being before god thus managed to attract followers from relatively lower stratum in the Arabian society at its' first inception.

Strong and enduring relation between charitable activities and religion is not only a privilege enjoyed by Islam. All monotheistic religion such as Judaism, Christianity, and Islam, like other religious traditions, have at least a set of guidance about how to live in society where social ailments such as poverty and deprivation exist as social fact. Social ailments such as poverty and others serve a purpose since it is believed that nothing is created without functions. They serve something, however miniscule it is.

The spirit of charity inherent within religion like Islam and others reflect the social purpose of religion, namely to bring prosperity and social justice to everyone. Religions, however, has played a pivotal role in the shaping of the very fabric of civilisations upon which the modern world today is founded.

The emergence of secular nationstate system as a result of cultural, industrial, and economic revolution that happened mostly in the west not only halted the territorial expansion of ArabMuslims but also has effectively ended the previous world-system based on religion of Islam. The core of the new system of drawing the map of the globe is inherently secular where the authority of religious figures is substituted by the authority of popular votes.

Many people predicted that religion would disappear as soon as democracy, a direct result of social revolution, managed to spread around the world. The emergence of welfare state as a continuation of the secularizing world has affected the way religious idea of caring others is exercised. The purpose of the welfare state to deliver social services to the people intersect with the main purpose of Islamic charity organizations thus pushing them into exploring new ways in building ties with the state.

\section{Islamic Charity in the Secular World: Some Theoretical Underpinning}

The word charity came from Latin word caritas which mean love. It is understood that the idea of charity represent one of many expression of love towards other by helping those who are poor and less fortunate in society. However, the interpretation of how charity should be implemented is never monotonous and has always been interlinked with various interpretation of religious teachings concerning helping others who are in need.

In ancient times, helping the poor and the less fortunate in society was done through direct means. In the modern world, the act of charity has been eroded by the expanding role of the welfare state. Poor and less fortunate people who previously was burden of the 
Showcasing Social Piety...hal. 168-179 community now become the burden of the state.

In the Judeo-Christian tradition, charity is believed to be the cornerstone of the todays' welfare state structure. It is the competition of definitions between that of the Judaism and Christianity that shaped the way the structure of social welfare functions as it is today. How each religious tradition perceive the idea of charity is by definition vary over times and places. Charity as an idea never stands alone in a vacuum. Instead, societal context upon which the society lives shapes and reshapes it. Regarding how the idea of charity affects the structure of social welfare system in many countries around the world, it is best to look at it as representation of the relation between values and actions that exist in society.

In Judaism, the word charity is closets in meaning with the concept of tzedakah. However, tzedakah does not merely mean love as charity is but means righteous or social justice. By defining tzedekah as charity, the idea of charity as another expression of love changes into the notion of entitlement. Thus, charity is closely associated with those who are entitled to receive help in society. It, again, reflect the communitarian nature of helping system, a sense of social obligation to help the poor and the less fortunate, that predates the current structure of welfare state system found in almost every part of the globe (Friedman, 2002, pp. 5-7).

The Christian tradition of charity is different from that of the Judaism although not in principal level. Friedman argued that since Jesus lived during the period full of unrest in society where there were split between bringing communal sacrifices into the temple or individualised prayers, Jesus were more focused on the idea of the needs to love one's fellow humans. Jesus, thus, looked beyond tzedekah as an obligation towards the poor and taught his people to love their fellows through any best possible means. In the word of Friedman, "Jesus taught it was better to teach a man to fish that to give him fish" since the former would enable the man to eat forever while the later would only enable him to eat for one day. This Christian tradition of caritas (the Latin origin of the word charity) thus relates to a more individualized way of dealing with poverty in society. Helping the poor was not only understood as a fixed obligation with a fixed amount of resources to be given to the society but went beyond to the idea of giving full sacrifice to help fellow humans who are in need (Friedman, 2002, pp. 8-10).

Just like other religious traditions, Islam evolves over time and place in order to survive. It accommodates changes that occur in society regarding how people interact thus making reinterpretations of various norms and values written on its holly scripture possible, even necessary. It is through the process of reinterpretations that Islam as a religion in its doctrinal senses and as a set of social norms containing guidance on how people should live their life managed to overcome difficulties. However, as any other religion, there are always a strand of interpretation that 
want to halt the process of such reinterpretation due to fear of Islam loosing it's purity as a religious dogma.

Regarding the concept of charity, Islam, as both a continuation of and a demarcation from the Judeo-Christian tradition, has numerous similarities with the later. Especially with Judaism, Islam puts great emphasis on divinely revealed laws that consist mainly of two areas; the ibadat and the muamalat. The Ibadat area of Islam concerns on issues related to worship while muamalat is more concerned with issues on social relation among people in society. The Islamic law, popularly known as sharia, therefore is supposed to be moral sources for public laws.

Of the three monotheistic religions, Islam is considered the only religious tradition that put disbursement of personal wealth for the welfare cause as an article of true faith, along with the Shahadah, Fasting in Ramadan, daily prayers, and making pilgrimage to Mecca (Jawad, 2009, p. 48). In fact, in Islam there are at least three distinct mechanism by which the disbursement of personal wealth could be disbursed; Zakat, Sodaqah, and Waqf.

Zakat refers to a fixed amount of wealth one must disburse according to the amount of wealth one possessed. This type of charity is obligatory for every Muslim who are not in the lower stratum economically thus allowing the emergence of debate around the question of should this type of almsgiving practice be categorised as charity. Sodaqah is another mechanism similar to zakat. While Zakat is a religious duty aimed at purifying one's soul and property/wealth, Sodaqah is not compulsory and its' main purpose is to help those in needs. Sodaqah has no fixed percentage while Zakat is considered to be 2.5 percent of one's earnings each year. In this regard, Sodaqah is more likely to be classified as charity (Fauzia, 2013, p. 62).

However, the notion of Islamic charity in the form of Zakat, Sodaqah, and Waqf, is not immune to changes thus the dynamic of their interpretation allows several competing definitions to exist and compete to each other. In this context, it is, thus, helpful to distinguish between Islam and Islamism. While Islam is more concerned with dogmas, doctrines, and values open to fresh interpretation, Islamism reflect the political side of Islam thus it concerns is primarily about power distribution in society.

Islamists' conception of charity, therefore, is different from the conception of charity in Islam as religious faith. The grey area of differences primarily lie on the ground of who has the authority to define several Islamic terms that refer to charity. Islamists' conception of charity follows the Islamist' totalitarian ideology of conserving the faith by not allowing other definition to exist and influence the public discourse in society. Thus, charity in Islamists' point of view is less concerned about its' definitions but more about the ends such practices want to achieve. In other words, to what cause charity must stands is more important than what charity really means 
Showcasing Social Piety...hal. 168-179 because charity is understood mainly as a means towards an end. ${ }^{1}$

In this regard, religion, especially Islam, based charity institutions differ in their strategy to deal with the secular nation-state. Since the secular nationstate system enjoyed great acceptance around the world, including in almost every Muslim countries, as a political system that fits the demand of modernity, the idea of Islamic charity must somehow fits the demanding requirement of modernity in order to gain acceptance from the general public that they serve.

While it is widely accepted that modern welfare state emerged out of modernization, theoretical explanation about to what extent industrialisation, or, to be more precise, modernization contribute to the establishment of welfare state is not always elaborated well. It is argued that the industrial revolution led to the emergence of the need for social security and other provision which can only be delivered by the state since the traditional burden sharing of the feudal society is no longer available. It is, therefore, not an exaggeration to say that "it was technical rationality rather than political conflict" that lead to the emergence of welfare state (Kersbergen \& Manow, 2009, p. 7).

The compromise between two seemingly opposing views of modernisation, hence secularism, and religious ideals of charity resonates well in the emergence of new phenomenon

\footnotetext{
${ }^{1}$ For a comprehensive account on the relation between Islamism and totalitarianism, please refer to (Tibi, 2009)
}

known as neoliberal piety. The unique relation between performing piety though practising charity and exercising technical rationality resulted in the emergence of neoliberal piety in which conflicts around political standpoints between free market capitalism and Islamic ideals of charity are not substantial. The two often seem to be complementing each other in ways that unseen before.

It is not helpful, thus, to understand the difference responses of many religion based charities regarding the question of who should provide social services to the poor and the less fortunate in society based on the dichotomy of religious and secular idea of living in society. This question should be addressed by framing the debate around religion based charity and the secular ones according to their places in a continuum where fundamentalist leaning of religion is places in one point and purely secular one at another point.

Drawing from religious movements in the United States, Italy, Egypt, and Israel, Davis and Robinson argued that regarding the provision of social services to their constituents and for the general public, religion based charity organization, especially those coming from fundamentalist leaning, represent two different identities, namely cultural authoritarianism and economic egalitarianism (Davis \& Robinson, 2012, pp. 12-13).

Cultural authoritarianism and economic egalitarianism are derived from the same notion of theological communitarianism which places the idea 
of expressing piety through seeking others in need. In this sense, one cannot become fully pious unless one is committed to both serve God and serve their community. Where serving God is manifested by following strict rules revealed by God in holly books or rabbinic interpretation of them, serving fellow humans can only be fulfilled by caring for others.

In this point of serving other fellow humans that religion based charity differs in their applied and proposed strategies.

Religious movements regarding social services provision in country where advanced system of social welfare is already in place, the caring features of religion is demonstrated by communitarian spirit of taking care of each other thus allowing them to obviate the need for a strong welfare state such as the case of Communione $\mathrm{e}$ Liberazione (CL) in Italy. The case of SHAS in Israel is somewhat similar to that of the CL. The SHAS, of which most the constituents come from Mizrahim or oriental Jews, managed to penetrate the government of Israel in order to push their agenda of economic egalitarianism in the form of generous welfare spending for the Mizrahi community and for the general public of Israelis. SHAS and CL may seems different in their strategy of dealing with the secular state where advanced system of social welfare are already put in place yet those two religious movements are similar in their long run goals, namely advancing both cultural authoritarianism and economic egalitarianism at the same time (Davis \& Robinson, 2012).
In a weak welfare state like in the United States, religious movements of similar agenda like the Salvation Army also apply similar strategy of sidestepping the state by creating parallel institutions where the state in no longer the sole player in delivering social services to those in need and those who are less fortunate in society. The Salvation Army in the US align closely with the Left (in conventional politics) since they both share the same goal of advancing economic egalitarianism. While they may differ in the area of cultural issues such as abortions, gay marriage, and a host of others, the Salvation Army has been successful in managing those differences by allowing its' potential members or donors through various ways depending to their level of commitments. From giving few dollars to becoming full and committed members of the movement.

The idea of sidestepping the state or making surrogate state is quite popular among Muslim majority countries where a combination of weak welfare system and staggering social problems exist for decades. In the post-caliphate of Ottoman, following the end of colonialism, many Muslim countries found themselves under the authoritarian regimes that put in places by their former colonizers such as found widely in the Middle East. This new authoritarian government was ineffective in running the state institutions thus allowing alternative institutions to flourish and act as a surrogate state, or a state within a state. Alternative institutions that provide welfare to the people, theoretically, not only could rival the 
Showcasing Social Piety...hal. 168-179 state in the long run but also could eventually take over power from the regime.

This process of taking over power in a relatively peaceful manner coincide with the inherent spirit within many Islamist groups that provide those welfare provisions, be it in the form of building hospital, discount stores, or martyr incentives in an extreme case like in Gaza, to Islamize society from below.

At this point, the compatibility between modernity, with democracy and secularism as its derivatives, and the political ideology of Islamism is at stake. Many questions such as could those who run the surrogate state embark democracy once they are in power soon arise since many believed that the act of providing welfare to general public is another way of resurrecting the political face of Islamism of the past when they failed to wage violence as an effective means toward achieving such end. ${ }^{2}$

Although answer for such question is far from exhaustive, it seems fair to give a try for alternative institutions of welfare provision to prove that they are capable of not only taking power from authoritarian regime of their country but also has the capacity to run the state and embark democracy as the most vital requirement for a strong welfare state.

\section{Islamic Charitable Organizations in Indonesia}

Islamic charitable organizations in Indonesia share a host of similarities

\footnotetext{
2 An exhaustive account on the potential and possible relationship between charity and jihad in the Islamic world can be read in (Burr \& Collins, 2006)
}

with those in the Middle East and other parts of Muslim countries. They deeply anchored in the spirit of helping others as depicted on the holy Qur'an and numerous prophetic traditions known as hadiths. They represent the dynamic of understanding Islamic teachings regarding the notion of hablumminannas, an ideal form of relationship among people in society.

Since before the inception of Indonesia as modern nation-state as a product of post colonialism. Muslim in the archipelago, known as Nusantara, has practiced philanthropy and other forms of charity mostly though nonformalized means. Many scholars even argue that before Islam came to Nusantara, many form of almsgivings parallel to modern charity was also widely practiced among people in society.

Depicting charity as a common practice of among lay people in the pre modern Indonesia is not an exaggeration, especially if the fact that pre modern Indonesia was a golden age of HinduBuddhist traditions. In this particular period of Indonesia history, the tradition of giving alms to ascetics is among many popular practice. Furthermore, giving practices such as gifts from kings to lay people was considered not only as a representation of the kings' generosity but also as a political mean to seal the loyalty of those lay people to their kings. In this context, such cultural practices that in today's world would be considered charity was not purely charitable in nature but was successful in 
providing a fertile ground for charity to thrive in the future.

When Islam came to Indonesia, it is quite safe to assume that those Muslim da'is (propagators) did not try to radically change many existing cultural practices that were widespread in the archipelago but instead tried to "Islamize" them. In this regard, charitable practices in the archipelago caught significant interest among those early Muslim preachers since they were, theoretically, traders cum proselytizers. These early Muslim proselytizers has had the financial means to attract people into Islam and the existing giving practices among lay people in that particular period of time would not found the "new Islamic practice of giving others" alien since they also had been practising similar practice by their own.

This context was indeed a very fertile ground for the proliferation of many Islamic charitable organization in the future when the archipelagic country transformed itself into a modern nationstate. However, pre-Islamic cultural practices regarding almsgivings in the country is not the only cornerstones for the establishment of future charitable institutions in the country. Other significant hallmarks that can be mentioned are the politics of noninterference applied by the Dutch colonial government and, later, the struggle of Indonesian people to defend the newly gained independence from Japanese imperial army (Fauzia, 2013).

The politics of non-interference applied by the Dutch colonial government laid the foundation of secular nation-state in Indonesia concerning the practice of almsgiving. In this period of Indonesian history, many charitable organization such as Muhammadiya's PKU (Pembina Kesejahteraan Umat - Social service provider for the Ummah) had gained momentum to spread its wings. So did the social welfare wings of other Islamic mass organizations in Indonesia such as Nahdlatul Ulama (NU - the awakening of the Scholars) and Masyumi.

When the Japanese imperial army effectively decimated the Dutch power in Indonesia during world war two, the Japanese initially tried to use the existing social institutions in Indonesia to support its great Asian war. The Japanese tried to mobilize these social forces to support their military campaign but failed. This failure, to some extent, signifies the solid secular basis of many of these charitable institutions. So when the Japanese imperial government tried to mobilize many Islamic charitable institutions under the banner of great holy war (Jihad), they eventually failed since these charitable institutions were so secular that they could not support the narrative of being under command of "religious" ruler.

During the period of war of independence, Muhammadiyah and NU became the most significant contributors of social services to the mass. Their already established social institutions allowed them to give massive contributions for the people during this crisis. When Muhammadiyah has been prominent in providing social services in the form of health and education, NU has been more concerned with 
Showcasing Social Piety...hal. 168-179 community development. The origin of these different paths of contributing to the people can be traced to the fact that Muhammadiyah's stronghold is located in the urban while NU build its' stronghold mostly in rural areas.

Indonesia was hit, severely, during several period of political instabilities in the country in its post-independence history. One of the most significant ones is the massacre of hundreds of thousands people during the massive extermination of communist party members and sympathizers in 1965s.

Many believed that in the core of such atrocity like the mass killing of 1960s in Indonesia lied a conflict regarding the implementation of social justice among ordinary people. Since many of the Indonesia Communist Party members were landless peasants, the attempted coupe to overrun the country was a struggle to share the country's prosperity more justly. Thus, it is of course not a coincidence that the Indonesian Communist Party's most prominent promise to the mass was about to perform land reform (reforma agraria) aimed at distributing equal share of land among peasants in the country.

From an Islamic point of view, this tragedy provides a unique opportunity to observe the dynamic interplays of the idea of social justice. It is quite the norm to perceive social justice as an end that can be achieved through practising charity in the form of generous giving practices as in the case of shadakah, zakat, and others. However, it is not only the way to see how social justice could be achieved in society. In fact, there are several lenses that has been in competition regarding how should society perceive the ideal version of performing social justice.

One of such lenses is the notion is to see the practice of almsgivings as a rights of the poor and the less fortunate. In fact, this point of view is not alien in the Islamic teachings regarding almsgiving such as in the practice of Zakat, Shadakah, and others. Moreover, it is also not alien to the lay people of Indonesia since a sort of this practice can be found, for example, in the traditional practice of bawon ${ }^{3}$ system (Retsikas, 2014).

From this angle, the Islamic practice of almsgiving in the form of Zakat and others could lose its privilege as a charitable practice since it is not only about the generosity of the rich but also about the rights of the poor. However, almost all major Islamic charitable organizations in Indonesia see the practice of Zakat, infaq and shadakah

${ }^{3}$ Bawon system refers to a practice of harvesting among peasants in Java. In the bawon system, everybody, without exception, could enjoy the harvest during harvesting season due to its open nature. In the Bawon system of harvesting, everybody could join the harvest not because the landlord generously allow them to do so but because the harvesters, most of those are landless peasants, also has rights to the land. So even though the land owner do not want some potential harvesters to join the harvest, he cannot deny their rights to join the harvest because this is perceived as the basic rule of the game. 
through the lens of generosity of the rich, as can be seen in the Muhammadiyah's donation page ("lazismu | memberi untuk negeri," n.d.), NU's care programme ("NUcare.id | Peduli \& Berbagi," n.d.), and ACT's international relief campaign ("Aksi Cepat Tanggap - Lembaga kemanusiaan," n.d.).

Seeing charitable practices through their other dimensions, namely rights of the poor, is scarce. Perhaps, it is because applying such lens come with risks of losing popularity among potential donors who used to practice almsgivings as their personalized social piety. Moreover, in todays' modern nation-state of Indonesia, the notion of rights of the poor fits the narrative of the function of welfare state more appropriately. Although the majority of charity funds provider agree on the long term purpose of religious charity such as Zakat and others, they still see the social problem in society such as chronic poverty as a burden that should be kept mainly on the shoulder of the state. Private religious charitable institutions are used to see themselves as helping the state thus allow them to build the narratives of Zakat and other giving practices under the banner of personalized social piety (Halimatusa'diyah, 2015).

\section{Concluding Remarks}

How charity is represented is not only about strategy to reach potential donors, it is also a representation of a particular understanding about such practices. Regarding charitable practices which has deep roots in Islamic teachings, how such practices is depicted is a significant marker that distinguishes one charitable organizations to others. This distinction does not only provide identity for such social institution but also provide a basis for long term supports of their potential constituents and donors.

Zakat, fitrah, and other aspects of Islamic teachings are widely accepted as a form of charity, or philanthropy. It is common to put those Islamic practices parallel to caritas and tzedekah that have their roots in Christianity and Judaism. However, such Islamic practices of helping fellow humans can also be seen as a rights entitled to the poor and the less fortunate among people in the society.

This particular way of understanding giving practices among Muslims serves a point of departure to acknowledge that social ailments such as poverty and others come from God as a test both for the rich and the poor. For the poor, such social ailments should be considered as a test to prove their submission to God. And for the rich, they serve as a test to prove their capacity to overcome basic human instinct of greed. Thus, acknowledging Zakat and other such practices of helping others as a rights entitled to the poor by God Himself would allow the poor to maintain their dignity while at the same time it would allow the rich to escape the trap of riya', which is highly forbidden in Islam.

\footnotetext{
${ }^{4}$ Riya' refers to the idea that Muslims should keep in mind that everything they do should be aimed at pleasing God. In the context of helping practices like Zakat and others, Muslims are obliged to free them self from the desire to be
} 
Showcasing Social Piety...hal. 168-179

Bibliography

Aksi Cepat Tanggap - Lembaga kemanusiaan. (n.d.). Retrieved July 20, 2018, from https://act.id/

Burr, M., \& Collins, R. O. (2006). Alms for jihad: charity and terrorism in the Islamic world. Cambridge ; New York: Cambridge University Press.

Davis, N. J., \& Robinson, R. V. (2012). Claiming society for God: religious movements and social welfare Egypt, Israel, Italy, and the United States. Bloomington: Indiana University Press.

Fauzia, A. (2013). Faith and the state: a history of Islamic philanthropy in Indonesia. Leiden; Boston: Brill.

Friedman, B. D. (2002). Two concepts of charity and their relationship to social work practice. Social Thought, 21(1), 3-19. https://doi.org/10.1080/1542643 2.2002.9960304

Halimatusa'diyah, I. (2015). Zakat and Social Protection: The Relationship between Socioreligious CSOs and the Government in Indonesia. Journal of Civil Society, 11(1), 79-99. https://doi.org/10.1080/1744868 9.2015.1019181

Jawad, R. (2009). Social welfare and religion in the Middle East: a Lebanese perspective. Bristol ; Portland, OR: Policy Press.

Kersbergen, K. van, \& Manow, P. (2009). Religion, class

praised by fellow humans because of their good deeds. coalitions, and welfare states. Cambridge: Cambridge University Press.

lazismu $\mid$ memberi untuk negeri. (n.d.). Retrieved July 20, 2018, from https://www.lazismu.org/

NUcare.id | Peduli \& Berbagi. (n.d.). Retrieved July 20, 2018, from https://nucare.id/

Retsikas, K. (2014). Reconceptualizing Zakat in Indonesia: Worship, Philanthropy and Rights. Indonesia and the Malay World, 42(124), 337-357. https://doi.org/10.1080/1363981 1.2014.951519

Tibi, B. (2009). Islamism and Democracy: On the Compatibility of Institutional Islamism and the Political Culture of Democracy. Totalitarian Movements and Political Religions, 10(2), 135164. https://doi.org/10.1080/1469076 0903192073

Tibi, B. (2012). Islamism and Islam. New Haven: Yale University Press. 